Спасіченко О.В.

Національний транспортний університет

\title{
ДОСВІД ОПТИМІЗАЦІЇ МАРШРУТНОЇ МЕРЕЖІ МІСТА ЗА ЕКОЛОГО-ЕКОНОМІЧНИМИ ПОКАЗНИКАМИ
}

\begin{abstract}
У роботі запропоновано для моделювання маршрутної мережі застосовувати метод лінійного програмування (транспортна задача) із критеріями оптимізації показників економіко-екологічної та соціальної оцінки. Особливістю цільової функції є адитивний характер показників економічних витрат, екологічних та соціальних збитків при здійсненні пасажироперевезень 3 ваговими коефіцієнтами і характеризує витратність логістичної системи. Для кожного маршруту вибирається відповідно вагові коефіцієнти важливості економічного та екологічного показників залежно від особливостей здійснення перевезення, що дозволяє вибрати схему перевезення за інтегральним показником (розраховується план оптимальний за економічними чи екологічними показниками, або компромісний). Розроблений підхід застосовано для удосконалення маршрутної мережі громадського транспорту м. Києва на еколого-економічних засадах. Оптимізація маршрутної мережі тільки для окремих маршрутів дозволила збільшити дохід і зменшити витрати при здійсненні пасажироперевезень з одночасним зменшилися викиді шкідливих речовин.

Ключові слова: транспортна система міста, маршрутна мережа, пасажироперевезення, оптимізація, еколого-економічні показники.
\end{abstract}

\section{ВСТУП}

Основним завданням транспорту на сучасному етапі є: забезпечення координації роботи різних видів транспорту на єдиній методологічній основі; забезпечення попиту на перевезення пасажирів та вантажів в умовах системної взаємодії двох і більше видів транспорту; забезпечення безпеки і якості перевезень; створення умов для фінансово-економічного оздоровлення транспортних підприємств і активізації інвестиційної діяльності; розробка науково-методичних і організаційно-технічних засобів супроводження процесів перевезень пасажирів та вантажів за умов взаємодії різних елементів в структурах логістики.

Транспортна стратегія України на період до 2020 року визначає ключові проблеми, цілі, принципи та пріоритети розвитку транспортної системи держави 3 точки зору загальнонаціональних потреб та інтересів, в тому числі пасажироперевезень міським пасажирським транспортом [1].

Сучасні стандарти життя висувають нові вимоги до рівня мобільності населення. Забезпечити зручний доступ до місця роботи, сфери обслуговування, до освітніх та культурних закладів i, зрештою, до місць проживання інших людей - це завдання номер один для транспортної системи міста. 3 цієї точки зору ефективне функціонування міського пасажирського транспорту має не тільки економічне, а також і велике соціальне значення. На мобільність населення має суттєвий вплив незадовільний розвиток транспортної мережі та маршрутної системи, нераціональне використання транспорту загального користування, низька якість транспортного обслуговування, зменшення парку автобусів, недосконалість системи швидкісних та експресних автобусних маршрутів у містах та заміських сполученнях.

Разом $з$ цим, під час експлуатації автотранспортних засобів відбувається значне забруднення довкілля. В атмосферне повітря потрапляють викиди парникових газів $\left(\mathrm{CO}_{2}, \mathrm{CH}_{4}\right)$, озоноруйнівних речовин (фтор, хлорвмісні вуглеводні, тобто канцерогени), шкідливі речовини $\left(\mathrm{NO}_{x}, \mathrm{SO}_{2}, \mathrm{CO}, \mathrm{NH}_{3}\right.$, розчинники), пил. В результаті інтенсивного руху за рахунок зношування асфальтових покриттів збільшується вміст твердих часток у повітрі, в тому числі канцерогенних. Значні збитки довкіллю наносять стічні води автотранспортних підприємств, які забруднені спрацьованими нафтопродуктами, оливами тощо. Забруднюють середовище матеріали, які використовуються під час ремонту, обслуговування і заправки транспортних засобів. Токсичними є змащувальні матеріали (моторні, трансмісійні і ін.) і рідини на мінеральній основі, які застосовують для гідросистем, клеї і герметики на основі формальдегідних і епоксидних смол, які застосовуються під час ремонту і виробництва автомобілів. Обсяг викидів речовин пересувними джерелами в Україні становить щорічно понад 1,7 млн т, або більше третини від загальної кількості викидів [2].

Вплив транспортної діяльності на здоров'я людини здійснюється через постійне забруднення повітря, шум, забруднення води і грунтів (особливо в аваріях при транспортуванні небезпечних товарів і вантажів), вплив на психічне здоров'я. Забруднення міської території викидами діяльності 
автомобільного транспорту є однією з причин підвищеної захворюваності населення. Особливо гострою ця проблема є у великих містах України, таких як Київ, Дніпро, Харків, Одеса та ін.

Рішення функціонального рівня найчастіше спрямовані на підвищення ефективності використання палива у вантажоперевезеннях, оптимізацію маршрутизації автотранспорту та енергозбереження. Отже, важливим напрямом зниження антропогенного навантаження на довкілля та скорочення суспільних витрат є оптимізація маршрутної мережі транспорту міста.

Таким чином, враховуючи те, що транспортна система багатьох міст України не відповідає стандартам і вимогам СС, виникає необхідність вирішення сукупності питань удосконалення транспортних мереж міст, раціонального використання транспортного потенціалу на засадах екологічної логістики та підвищення рівня екологічної безпеки, як однієї з основ сталого розвитку транспорту.

\section{АНАЛІЗ ЛІТЕРАТУРНИХ ДАНИХ ТА ПОСТАНОВКА ПРОБЛЕМИ}

Питання управління системами міських пасажирських перевезень міського автомобільного транспорту розглянуто в дослідженнях [3]. Автором визначена роль автомобільного транспорту в глобальній економіці та розвитку сучасного суспільства. Показано, що транспорт є одним 3 найпотужніших джерел локальних $\mathrm{i}$ глобальних викидів забруднюючих речовин. $\mathrm{y}$ роботі запропоновано механізм визначення джерел викидів на всьому життєвому циклі транспортних засобів.

Науковий аналіз підходів, методів та інструментів екологічної («зеленої») логістики, логістики ресурсозбереження і відходів, формування екологічно орієнтованих стратегій поведінки логістичних суб'єктів здійснено в дослідженнях Julian Allen, Daniel Black, Anthony Whiteing, Michael Browne, Yingli Wang, Julia Edwards, Maja Piecyk та ін. [4,5].

Проблему розвитку та провадження концепції сталого розвитку вивчало багато авторів, зокрема: Ю.Ф.Гутаревич, Д.В.Зеркалов, А.Г.Говорун, А.О.Корпач, Л.П.Мержиєвська вивчали досвід реалізації стратегії сталого розвитку [6].

Вплив на навколишнє середовище підприємств найчастіше досліджувався лише для окремих логістичних процесів, наприклад, транспортних перевезень, складування, або процесів поводження 3 відходами (Смешек М., Матейчик В., Хрутьба В. [7]).

В дослідженнях Матейчика В.П., Цюмана М.П. [8] проаналізована екологічна безпека транспортних засобів в умовах міського транспортного потоку 3 застосуванням методів математичного моделювання. В роботах $[9,10]$ сформовані пропозиції удосконалення міської машрутної мережі.

Лиштва М.O. [11] розглядає комплексний підхід до оптимізації системи міського пасажирського транспорту на прикладі транспортних проблем міста Києва.

Проте, в умовах постійних економічних змін, збільшення пасажиропотоків в міських транспортних системах та посилення екодеструктивного впливу транспортної діяльності на довкілля, визначена проблема потребує подальшого дослідження.

\section{ЦІЛЬ ТА ЗАДАЧІ ДОСЛІДЖЕННЯ}

Метою роботи $€$ визначення та дослідження динаіки розвитку міського пасажирського транспорту та розробка пропозицій щодо підвищення економічної та екологічної ефективності його функціонування.

Завданням дослідження $є$ : охарактеризувати особливості розвитку міського пасажирського транспорту; запропонувати підхід до моделювання маршрутної мережі громадського транспорту міста; застосувати розроблений підхід для удосконалення маршрутної мережі громадського транспорту м.Києва на еколого-економічних засадах.

\section{РЕЗУЛЬТАТИ ДОСЛІДЖЕНЬ}

Згідно даних Міністрерства інфраструктури України [12] на даний час автомобільна транспортна система в Україні налічує понад 9,2 млн. транспортних засобів, у тому числі 6,9 млн. легкових автомобілів, $\approx 250$ тис. автобусів, $\approx 1,3$ млн. вантажних автомобілів, понад 840 тис. од. мототранспорту. На ринку комерційних перевезень здійснюють підприємницьку діяльність майже 56,2 тис. перевізників, які використовують більш 154 тис. транспортних засобів. У міському сполученні перевезено 5407 млн. пасажирів з них: автомобільним транспортом (автобуси) 2575 млн., тролейбусами 1300 млн., трамваями 757 млн., метрополітеном 775 млн. Пасажирообіг автомобільним транспортом (автобуси) становить:

-49 млр. пас. км, що становить 38 \% від всіх видів транспорту;

- тролейбусами - 7,6 млр. пас., що становить $6 \%$;

- трамваями - 4.1 млр. пас. км, що становить $3 \%$. 
У таблиці 1 представлені дані щодо виду перевезень та кількості діючих ліцензій в галузі [12].

Таблиця 1 - Види перевезень та кількість діючих ліцензій

\begin{tabular}{|l|c|}
\hline \multicolumn{1}{|c|}{ Вид перевезень } & Кількість діючих ліцензій \\
\hline надання послуг з перевезення пасажирів автобусами & 13295 \\
\hline надання послуг з перевезення пасажирів на таксі & 15965 \\
\hline $\begin{array}{l}\text { надання послуг з перевезення пасажирів легковими автомобілями на } \\
\text { замовлення }\end{array}$ & 987 \\
\hline надання послуг з перевезення небезпечних вантажів & 1820 \\
\hline надання послуг перевезення пасажирів та небезпечних вантажів & 206 \\
\hline надання послуг перевезення пасажирів та вантажів & 636 \\
\hline надання послуг з перевезення вантажів & 12451 \\
\hline \multicolumn{1}{|c|}{ Всього } & 45360 \\
\hline
\end{tabular}

Планування раціональної організації маршрутної мережі з урахуванням вимог пасажирів i підприємств рекомендуємо здійснювати за комплексним методом, сутність якого полягає у мінімізації витрат, відповідно моделі оптимізації еколого-логістичних потоків підприємств за системою показників - економічних (витрати по розподілу і доставці продукції), екологічних (витрати по зниженню антропогенного навантаження на довкілля) та соціальних (витрати, спрямовані на задоволення потреб споживачів послуг).

Для моделювання маршрутної мережі громадського транспорту міста пропонується застосувати метод лінійного програмування (транспортна задача) із використанням як критерії оптимізації показники економіко-екологічної та соціальної оцінки. Цільова функція $є$ адитивною функцією показників економічних витрат $\left(Y_{1}^{E}\right)$, екологічних $\left(Y_{2}^{Д}\right)$ та соціальних $\left(Y_{3}^{C}\right)$ збитків при здійсненні пасажиро та/або вантажоперевезень з ваговими коефіцієнтами і характеризує затратність логістичної системи при формуванні маршрутної мережі транспорту міста.

$$
\begin{gathered}
K=\lambda_{1} \cdot Y_{1}^{E}+\lambda_{2} \cdot Y_{2}^{\text {म }}+\lambda_{3} \cdot Y_{3}^{C} \rightarrow \min \\
\lambda_{1}+\lambda_{2}+\lambda_{3}=1 \\
Y_{1}^{E}=h_{i}\left(x_{1}^{\prime}, \ldots, x_{n}^{\prime}\right) \leq a_{i}, \quad i=\overline{1, l} \\
Y_{2}^{\text {म }}=g_{k}\left(x_{1}^{\prime \prime}, \ldots, x_{n}^{\prime \prime}\right) \leq b_{k}, \quad k=\overline{1, p} \\
Y_{3}^{C}=\varphi_{m}\left(x_{1}^{\prime \prime \prime}, \ldots \ldots . ., x_{n}^{\prime \prime \prime}\right) \leq c_{m}, \quad m=\overline{1, t}
\end{gathered}
$$

де $x_{1}^{\prime}, \ldots, x_{n}^{\prime}, x_{1}^{\prime \prime}, \ldots, x_{k}^{\prime \prime}, x_{1}^{\prime \prime \prime}, \ldots, x_{m}^{\prime \prime \prime} \quad$ - дійсні змінні (керовані параметри).

де $K$ - інтегральний показник витратності логістичної системи маршрутної мережі міста; $\lambda_{1}, \lambda_{2}, \lambda_{3}$ - вагові коефіцієнти важливості кожного показника.

Для кожного маршруту вибирається відповідно вагові коефіцієнти важливості економічного та екологічного показників $\left(\lambda_{1}, \lambda_{2}\right)$ залежно від особливостей здійснення перевезення (табл.2), що дозволяє вибрати схему перевезення за інтегральним показником (розраховується план оптимальний за економічними чи екологічними показниками, або компромісний). 
Таблиця 2 - Рекомендації щодо вибору плану оптимізації маршруту перевезення

\begin{tabular}{|c|c|c|c|}
\hline Умова & $\lambda_{1}$ & $\lambda_{2}$ & Рекомендація \\
\hline$\lambda_{1}>\lambda_{2}$ & $(0,6 ; 1)$ & $(0 ; 0,4)$ & Оптимальний за економічним показником \\
\hline$\lambda_{1} \approx \lambda_{2}$ & {$[0,4 ; 0,6]$} & {$[0,4 ; 0,6]$} & Компромісний план \\
\hline$\lambda_{1}<\lambda_{2}$ & $(0 ; 0,4)$ & $(0,6 ; 1)$ & Оптимальний за екологічним показником \\
\hline
\end{tabular}

Оптимальний маршрут у вигляді оптимального плану перевезення формується за результатами вирішення транспортної задачі.

Застосуємо розроблений підхід для удосконалення маршрутної мережі громадського транспорту м.Києва на еколого-економічних засадах.

Місто Київ є великим адміністративним центром 3 багатомільйонним населенням. Для задоволення потреб жителів міста та забезпечення функціонування всіх сфер виробництва, обслуговування необхідне регулярне здійснення пасажиро- та вантажоперевезень. Однією 3 глобальних соціальних, економіко-екологічних проблем, що потребує нагального вирішення $€$ оптимізація маршрутної мережі транспорту міста за умови зниження викидів забруднюючих речовин пересувними джерелами. Зменшення впливу на зміну клімату реалізуючи політику стійкого розвитку транспортної системи міста дозволяє також отримати низку інших переваг, у тому числі покращення якості повітря, зменшення шуму, що спричинений транспортними засобами, підвищення рівня безпеки на дорогах, а також ряд соціальних та економічних переваг.

Транспортна система м. Києва включає в себе десятки автобусів, тролейбусів, трамваїв, маршруток, а також фунікулер. Загальна довжина автотранспортних магістралей, розташованих у межах міста, тобто проспектів, вулиць, бульварів тощо становить близько 2000 км. Більшість їх проклали ще в минулому сторіччі, але в сучасних умовах постійного зростання кількості одиниць автотранспорту, їх пропускна здатність виявляється недостатньою, унаслідок чого затори у Києві, особливо у години пік, стали повсякденним явищем. За нинішньою організацією руху, і низькою культурою водіїв затори регулярно виникають як на головних магістралях, так і на найближчих вулицях, які намагаються використовувати за для об'їзду. Переважна більшість доріг має асфальтове покриття, яке, на жаль, нині в задовільному стані перебуває лише на головних магістралях i нещодавно прокладених або реконструйованих дорогах.

Щоденно мешканцям Києва транспортні послуги надають 2964 автобуси різного класу (361 звичайний режим, 2603 - режим маршрутного таксі), які працюють в звичайному режимі руху та в режимі маршрутних таксі, 406 тролейбусів, 294 трамвайних вагонів, 645 вагонів метрополітену (3 лінії метрополітену, 51 станція), 60 вагонів міської "електрички". Транспортна мережа міста охоплює 302 автобусних (з них: 70 в звичайному режимі, 232 в режимі маршрутного таксі), 37 тролейбусних, 20 трамвайних маршрутів. Комунальне підприємство "Київпастранс" об'єднує у своєму складі 4 тролейбусні і 3 трамвайні депо, а також 8 автобусних парків. Важливою складовою транспортної системи м. Києва є метрополітен [13].

. У м. Києві здійснюється поступовий перехід до впровадження нових принципів організації та управління транспортним процесом шляхом використання сучасних автоматизованих систем. За цих умов проблема збалансованого i ефективного використання i розвитку міських пасажирських транспортних потоків набуває виключної актуальності, а іiі вирішення вимагає розробки i застосування сучасних підходів і методів і вимагає оптимізації маршрутної мережі.

При цьому вирішується задача мінімізації транспортних витрат при розподілі транспортного потоку в маршрутній мережі м.Києва за еколого-економічними показниками. Побудову оптимального маршруту пасажироперевезення будемо здійснювати для економічного $\left(k_{E}\right)$ та екологічного $\left(k_{\text {д }}\right)$ показників для конкретних маршрутів маршрутної мережі м.Києва. Для проведення дослідження було обрано маршрути пасажирських перевезень міста, характеристика яких приведена в табл. 3.

Для проведення необхідних розрахунків були проведені експериментальні спостереження за пасажиропотоками на обраних маршрутах. На підставі отриманих даних (а саме: середній час рейсу, середня кількість рейсів, годинна продуктивність одного автобуса за кількістю перевезених пасажирів, кількість автобусів за годинами роботи маршруту, коефіцієнт наповнення автобусів по 
кожній годині роботи маршруту, інтервал руху автобусів по кожній годині роботи маршруту) визначаємо режим роботи транспортних засобів.

Далі було досліджено економічну ефективність перевезень на обраних маршрутах.

Таблиця 3 - Характеристика вибраних маршрутів транспортної систми міста

\begin{tabular}{|c|c|c|c|c|c|}
\hline \multirow{2}{*}{ Показник } & \multicolumn{5}{|c|}{ Маршрут } \\
\hline & № 33 & № 55 & № 46 & № 79 & № 49 \\
\hline Вартість, грн & 8 & 8 & 8 & 8 & 8 \\
\hline Відстань & 5,96 & 12,42 & 8,13 & 9,02 & 8.26 \\
\hline Інтервал руху, хв & $16-23$ & $10-17$ & $8-12$ & $20-25$ & $14-26$ \\
\hline Час роботи & $\begin{array}{c}06: 00- \\
00: 19\end{array}$ & $05: 45-21: 58$ & $05: 35-2328$ & $08: 30-17: 59$ & $06: 25-23: 28$ \\
\hline $\begin{array}{l}\text { Довжина } \\
\text { нульового } \\
\text { пробігу, км }\end{array}$ & $3,6 / 4,6$ & $11,72 / 2$ & $3,6 / 4,6$ & $0,2 / 0,1$ & $3,6 / 4,6$ \\
\hline Робочі дні & \multicolumn{5}{|c|}{ Пн Вт Ср Чт Пт Сб Нд } \\
\hline Кількість зупинок & $15 / 16$ & $25 / 21$ & $16 / 15$ & $8 / 11$ & $15 / 16$ \\
\hline $\begin{array}{l}\text { Середня довжина } \\
\text { перегону, км }\end{array}$ & 0,46 & 0,46 & 0,49 & 0,46 & 0,46 \\
\hline $\begin{array}{l}\text { Час оборотного } \\
\text { рейсу, хв. }\end{array}$ & 50 & 50 & 60 & 30 & 50 \\
\hline
\end{tabular}

Згідно отриманих розрахунків за типом автобусу Богдан А-092 розрахована сума витрат на оплату праці, страхування, паливо, підтримку належного технічного стану автопарку та накладні витрати, а також прибуток.

Для здійснення екологічної оцінки маршрутів розраховано масові викиди шкідливих речовин $\left(\mathrm{CO}, \mathrm{C}_{\mathrm{m}} \mathrm{H}_{\mathrm{n}}, \mathrm{NO}_{\mathrm{x}}, \mathrm{PM}\right.$ та $\left.\mathrm{CO}_{2}\right)$ в повітрі за показниками пробігових викидів.

Для формування оптимального маршруту доцільно обрати план перевезень 3 врівноваженими економічними та екологічними ваговими коефіцієнтами. За допомогою цього плану здійснено оптимізацію маршрутів за еколого-економічними показниками. Економічними показниками оцінювалися витрати на перевезення пасажирів за традиційним і оптимальним маршрутами. Екологічні показники визначали збитки, які нанесені навколишньому середовищу викидами шкідливих речовин.

\section{ОБГОВОРЕННЯ РЕЗУЛЬТАТІВ ДОСЛІДЖЕННЯ}

В результаті порівняльної оцінки маршрутів одержано такі результати. Для всіх маршрутів збільшився дохід і зменшилися витрати. Зменшилися викиди шкідливих речовин - $C O$ у $4-4,6$ рази, $C_{m} H_{n}, y$ 2,7-3,0 рази; $N O_{x}$ у 2,3-2,7 разів, $P M$ у 5,3-6,0 разів і $C O_{2}$ у $1,5-1,8$ рази.

Розрахунок сумарного коефіцієнту еколого-економічної ефективності формування логістичної системи маршрутної мережі транспорту міста приведено в табл. 4.

Таблиця 4 - Розрахунок економічного ефекту від оптимізації транспортного маршруту, 2018 р, тис. у.од

\begin{tabular}{|c|c|c|c|}
\hline \multirow{2}{*}{ Показник } & \multicolumn{2}{|c|}{ Маршрут } & \\
\hline & Звичайний & Оптимізований & \\
\hline Витрати, тис. ум.од & 3652,28 & 3269,47 & $10,5 \%$ \\
\hline в т.ч. транспортні витрати & 1569,4 & 1467,5 & $6,5 \%$ \\
\hline Загальні екологічні збитки, ум.од & 145,1 & 130,5 & $10,1 \%$ \\
\hline Інтегральний показник витратності маршрутів & 5,5 & 1,6 & $70,9 \%$ \\
\hline
\end{tabular}

Таким чином, сумарні витрати на перевезення пасажирів після оптимізації досліджуваних маршрутів зменшилися на $10,5 \%$, в тому числі транспортні витрати на $6,5 \%$, а загальні екологічні 
збитки зменшилися на $10,1 \%$. Економія палива для одного транспортного засобу на один маршрут 23,2 л, що приводить до економія на вартості палива на 4,3 ум.од., скорочення транспортних витрат на 101,9 ум.од. та скорочення відверненого збитку від викидів в атмосферне повітря 14,6 ум.од. Мінімальне значення інтегрального показника виратності маршрутів знизилось на 70,9\%.

\section{ВИСНОВКИ}

Згідно 3 результатами дослідження, можна зробити висновок, що ефективним методом зменшення антропогенного впливу транспортної системи міста на довкілля є оптимізація маршрутної мережі громадського транспорту.

Для моделювання маршрутної мережі громадського транспорту міста застосовується метод лінійного програмування (транспортна задача) із використанням в якості критеріїв оптимізації показників економіко-екологічної та соціальної оцінки. Цільова функція $\epsilon$ адитивною функцією показників економічних витрат ( $\left.Y_{1}^{E}\right)$, екологічних $\left(Y_{2}^{\text {Д }}\right)$ та соціальних $\left(Y_{3}^{C}\right)$ збитків при здійсненні пасажиро та/або вантажоперевезень з ваговими коефіцієнтами і характеризує затратність логістичної системи при формуванні маршрутної мережі транспорту міста. Для кожного маршруту вибирається відповідно вагові коефіцієнти важливості економічного та екологічного показників залежно від особливостей здійснення перевезення, що дозволяє вибрати схему перевезення за інтегральним показником (розраховується план оптимальний за економічними чи екологічними показниками, або компромісний).

Розроблений підхід застосовано для удосконалення маршрутної мережі громадського транспорту м.Києва на еколого-економічних засадах. Оптимізація маршрутної мережі тільки для маршрутів дозволила збільшити дохід і зменшити витрати при здійсненні пасажироперевезень. Зменшилися викиди шкідливих речовин - $C O$ у $4-4,6$ рази, $C_{m} H_{n}, y \quad 2,7-3,0$ рази; $N O_{x}$ у 2,3 - 2,7 разів, $P M$ у $5,3-6,0$ разів і $C_{2}$ у $1,5-1,8$ рази. Сумарні витрати на перевезення пасажирів після оптимізації трьох досліджуваних маршрутів зменшилися на $10,5 \%$, в тому числі транспортні витрати на $6,5 \%$, а загальні екологічні збитки зменшилися на 10,1\%. Економія палива для одного транспортного засобу на один маршрут 23,2 л, що приводить до економія на вартості палива на 4,3 ум.од., скорочення транспортних витрат на 101,9 ум.од. та скорочення відверненого збитку від викидів в атмосферне повітря 14,6 ум.од. Мінімальне значення інтегрального показника виратності маршрутів знизилось на $70,9 \%$.

Отже, оптимізація маршрутної мережі транспорту міста в сучасних умовах $\epsilon$ важливою задачею інтеграції міста в європейське середовище. Узгодженість, раціоналізація економічна обгрунтованість та екологічна безпечність маршрутної мережі міста забезпечується ії формуванням за критеріями еколого-економічної ефективності. Розроблена еколого-економічна модель ефективності логістичної системи транспорту міста дає можливість оптимізувати рух потоку за визначеними критеріями еколого-економічної ефективності.

\section{ПЕРЕЛІК ДЖЕРЕЛ ПОСИЛАННЯ}

1. Про схвалення Транспортної стратегії України на період до 2020 року [Електронний ресурс]: Розпорядження Кабінету Міністрів України від 20 жовтня 2010 р., N 2174-р., Київ - Режим доступу: http://zakon4.rada.gov.ua/laws/show/2174-2010-\%D1\%80 - Заголовок з екрану

2. В В Влив транспорту на екологію міста. Аналіз та стратегії для України [Електронний pecypc]. - Режим доступу: http://urbanreform.org.ua/wp-content/uploads/2016/09/transportukr4_small.pdf

3. Шпильовий І.Ф. Методичні основи управління системами міських пасажирських перевезень. Дис...канд.техн.наук, Національний транспортний університет, 2010.-184 с.

4. Alan McKinnon The Chartered Institute of Logistics and Transport. Green logistics. Improving the environmental sustainability of logistics. / Alan McKinnon, Sharon Cullinane, Michael Browne, Anthony Whiteing // London, 2010. - 372 p.

5. Rahman M. H. Environmental sustainability of urban road transport: an integrated analysis for life cycle emission impact / M. H. Rahman, H. C. Chin. M. M. Haque // International J. of Environment and Sustainable Development. - 2014. - v. 13. - N. 2. - P. 126-141.

6. Гутаревич Ю.Ф. Екологія та автомобільний транспорт. Навч. посібник 2-ге вид. / Ю.Ф.Гутаревич, Д.В.Зеркалов, А.Г.Говорун, А.О.Корпач, Л.П.Мержиєвська. // К.: Арістей , 2008. $296 \mathrm{c}$.

7. Матейчик В.П. Особливості моделювання показників екологічної безпеки транспортного засобу при русі в потоці / В.П. Матейчик, Н.П. Цюман // Сучасні технології в машинобудуванні та транспорті. Луцьк: НТУ, 2016. - Вип.1 (5). - С. 99-103. 
8. Матейчик В.П. Управління проектами екологічної логістики транспортних підприємств / В.П. Матейчик, М. Смешек, В.О. Хрутьба // Наукові нотатки: міжвузівський збірник. Луцьк. - № 45, 2014 - C. $339-345$.

9. Khrutba V. O. The formation of the Kyiv Transport System environmental safety / V. O. Khrutba, O. V. Spasichenko, L. M. Starynets // Вісник Національного транспортного університету. Серія "Технічні науки", Випуск 3 (42). 2018. - С.172-181

10. Dmitrichenko N. Ecological and Economic Principles to Improve the Route Network of Urban Transport / N. Dmitrichenko, V. Khrutba, O. Spasichenko Y. Khrutba // Journal of Urban Economics and Management, Vol.6, No 1(21), Shahid Sattari Street, Valiasr Street, Tehran, Iran. - 2018 - p.131 -144.

11. Лиштва М.О. Оптимізація маршрутної схеми міського пасажирського транспорту на прикладі Солом'янського району міста Києва / М.О. Лиштва //Містобудування та територіальне планування, Випуск 24 (56). 2015 - С.80-82

12. Міністерство інфраструктури України (загальна інформація по галузі) [Електронний pecypc]. / - Режим доступу: http://mtu.gov.ua/content/zagalna-informaciya-pro-galuz.html

13. Офіційні дані КП "Київпастранс", 2019. URL: https:// kpt.kiev.ua.

\section{REFERENCES}

1. On approval of the Transport Strategy of Ukraine for the period up to 2020 (2010). Order of the Cabinet of Ministers of Ukraine № 2174-p.

2. The impact of transport on the environment of the city. Analysis and strategies for Ukraine (2016) http://urbanreform.org.ua/wp-content/uploads/2016/09/transport-ukr4_small.pdf

3. Shpileviy I.F. (2010) Methodical bases of management of urban passenger transportation systems. National University of Transport, $184 \mathrm{p}$.

4. Alan McKinnon, Sharon Cullinane, Michael Browne, Anthony Whiteing (2010) The Chartered Institute of Logistics and Transport. Green logistics. Improving the environmental sustainability of logistics. London, $372 \mathrm{p}$.

5. Rahman M. H., Chin H. C.. Haque M. M. (2014) Environmental sustainability of urban road transport: an integrated analysis for life cycle emission impact. International J. of Environment and Sustainable Development. v. 13, №. 2, 126-141.

6. $\quad$ Gutarevich Yu.F., Zerkalov D.V., Govorun A.G., Korpach A.O., Merzhievska L.P. (2008) Ecology and road transport. K.: Aristey, 296 p.

7. Matechyk V.P., Tsuman N.P. (2016) Features of modeling the environmental performance of the vehicle when in motion. Modern technologies in mechanical engineering and transport. Lutsk, v.1 (5), 99-103.

8. Matechyk V.P., Smeshek M., Khruba V.O (2014) Management of projects of ecological logistics of transport enterprises. Scientific notes: Intercollegiate collection. Lutsk, № 45, 339-345.

9. Khrutba V. O., Spasichenko O. V., Starynets L. M. (2018) The formation of the Kyiv Transport System environmental safety. Bulletin of the National Transport University. - Technical Sciences Series v. 3 (42), 172-181.

10. Dmitrichenko N., Khrutba V., Spasichenko O., Khrutba Y. (2018) Ecological and Economic Principles to Improve the Route Network of Urban Transport. Journal of Urban Economics and Management, Vol.6, No 1(21), Shahid Sattari Street, Valiasr Street, Tehran, Iran.,131 -144.

14. Лиштва М.О. Оптимізація маршрутної схеми міського пасажирського транспорту на прикладі Солом'янського району міста Києва / М.О. Лиштва //Містобудування та територіальне планування, Випуск 24 (56). 2015 - С.80-82

15. Міністерство інфраструктури України (загальна інформація по галузі) [Електронний pecypc]. / - Режим доступу: http://mtu.gov.ua/content/zagalna-informaciya-pro-galuz.html

16. Офіційні дані КП "Київпастранс", 2019. URL: https:// kpt.kiev.ua.

\section{economic indicators. \\ O. Spasichenko. The experience of optimization of route network of the city by ecological and}

The article presents a linear programming method (transport problem) applied to simulate the route network of a city. Optimization criteria are indicators of economic, environmental and social assessment. The objective function has indicators of economic costs, environmental and social losses when performing passenger transportation with weight coefficients. Weighting indices choose for each route the importance of economic and environmental indicators, depending on the characteristics of transportation. The scheme of 
transportation is chosen by the integral indicator (calculate the plan optimal for economic or environmental indicators, or compromise).

The developed approach is applied for improvement of the Kyiv public transport route network on the ecological and economic basis. Optimization of the route network only for individual routes allowed to increase the income and reduce the costs of commuting while reducing the emissions of harmful substances.

Key words: city transport system, itinerary network, passenger transportation, optimization, ecological and economic indicators.

СПАСІЧЕНКО Оксана Вкторівна, асистент кафедри екології та безпеки життєдіяльності, Національний транспортний університет, м.Київ, е-mail: Ksuxa14@meta.ua, https://orcid.org/0000$\underline{0002-7809-6765}$

Oksana SPASICHENKO, assistant of the Department of Ecology and Safety of Life, National Transport University, Kyiv, Ukraine, e-mail: Ksuxa14@meta.ua, https://orcid.org/0000-0002-7809-6765 